\title{
Investigating the Influence of Tourism on Economic Growth and Climate Change - The Case of Croatia
}

\author{
Zvonimira Šverko Grdić1, Maja Gregorići', Marinela Krstinić Nižić1
}

\begin{abstract}
In Croatia, tourism is one of the most important economic activities, accounting for $2.1 \%$ of total tourist flows in the European Union and 18\% of the total Croatian gross domestic product. Economic development and tourism flows are influenced by the increasing intensity of climate change, leading to a need to adapt to new business conditions to minimize the negative and maximize the positive effects. The objective of the current study is to empirically research the role of tourism in the Croatian economy for the period 2004-2015 and the impact of climate change on tourist flows. To investigate experts' opinions on the impact of climate change on Croatian tourism, this study employs a qualitative approach to obtain comprehensive insights into tourism, climate change and scientific research. By conducting in-depth interviews with experts and identifying the challenges posed by the current impact of climate change on Croatian tourism, the authors gain deeper insights into tourism development and climate change that reflect the current situation in Croatia. The results indicate that climate change will not have a negative impact on Croatian tourism in the near future. However, after 2050, a number of adaptation measures will be required to maintain the current tourism status.
\end{abstract}

KEY WORDS: $\quad$ economic development, tourism, climate change, Croatia

JEL Classification: A10, O20, Q50, Q58

${ }^{1}$ University of Rijeka, Faculty of Tourism and Hospitality Management, Croatia

\section{Literature Review}

The overall complexity of connections among tourism development, economic growth and climate change has been examined by only a small number of studies (Dell, Jones, \& Olken, 2012), either in quantitative or in qualitative terms (Eboli, Parrado, \& Roson, 2010). However, separate studies on the impact of tourism . on economic development and of climate change on

Correspondence concerning this article should be addressed to: Zvonimira Šverko Grdić, University of Rijeka, Faculty of Tourism and Hospitality Management, Primorska 42, 51410 Opatija, Croatia.E-mail:zgrdic@fthm.hr tourism development are conducted in great numbers. Many of those studies indicate a positive correlation between tourism development and economic welfare (Lee \& Brahmasrene, 2013; Schubert, Brida, \& Risso, 2011) and a correlation, either positive or negative, between tourism flows and climate change (Amelung, Nicholls, \& Viner, 2007; Gössling, Hall, Peeters, \& Scott, 2010; Hamilton \& Tol, 2007; Pickering, 2011).

Tourism has made a significant contribution to the economies of many communities around the world because of its ability to create government revenue income, taxes, employment, opportunities, and infrastructure (Lee \& Brahmasrene, 2013; Payne \& Mervar, 
2010). Tourism is considered an important factor that promotes economic development and contributes to the welfare of the local population (Webster \& Ivanov, 2014). Lee and Brahmasrene have proposed a tourism-led economic growth hypothesis that assumes tourism as a major factor in overall long-run economic growth (Lee \& Brahmasrene, 2013). A data analysis for 143 countries over the last 20 years has shown that small tourism countries achieved a faster rate of economic growth than nontourist countries, suggesting that tourism specialization was beneficial for growth (Brau, Lanza, \& Pigliaru, 2007). Theoretical analysis tends to posit that tourism expansion should contribute positively to economic growth, but some authors also claim that the opposite is true (Balaguer \& Cantavella-Jorda, 2002; Dritsakis, 2004; Figini \& Vinci, 2009; Seetanah, 2011). Some economists have emphasized that an economic approach to climate policy must compare the entire set of measures to choose a portfolio of cost-effective measures (Konrad \& Thum, 2013). As climate resilience emerges as an equally important development concern, it is worth asking which of the existing growth policies are compatible with adaptation and mitigation needs (Bowen, Cochrane, \& Fankhauser, 2012).

Public and political interest in climate change has increased considerably in recent years, especially after the United Nations Climate Change Conference in Copenhagen in December 2009 (Scott \& Becken, 2010). Climate change is a global challenge that requires a long-term global solution to avoid environmental, social, and economic dislocation (Dwyer, Forsyth, Spurr, \& Hoque, 2012). Tourism and tourism-related activities (transportation, accommodation and other activities) contribute to the emission of greenhouse gases into the atmosphere, which causes climate change. As a result, the industry has been targeted by the environmental movement, which advocates considerably reducing tourism activities and embracing measures to reduce greenhouse gas emissions, with some environmentalists going as far as to urge tourists to forsake travel away due to its discretionary nature and abovementioned impacts on climate change (Shani \& Arad, 2014). The World Tourism Organisation (UNWTO) and United Nations Environment Programme (UNEP) projections for 2005 have calculated that the total contribution of global tourism to climate change is signifi- cant, amounting to $5 \%$ of total $\mathrm{CO}_{2}$ emissions (Scott \& Becken, 2010). Transport is the dominant component of the tourism contribution, with air transport accounting for $40 \%$ of tourism's emissions (Dickinson, Robbins, Tilimonau, Hares, \& Mika, 2013). Emissions due to tourism are expected to grow because of several trends, including the following: growth in the number of people traveling for employment, business, leisure, education, and health services; continuing declines in the real cost of travel; increases in per capita disposable incomes leading to a growing number of trips made per capita; and growth in the average length of trips made, due to the greater speed of the transport modes used (Gössling, Scott, \& Hall, 2013). On the other hand, tourism depends on a favorable climate, a preserved environment and a richness of flora and fauna (Buckley, 2011; Müller \& Weber, 2008). Climatic factors, such as temperature, sunshine hours and rain, determine a large share of the international tourism flows within Europe (Amelung \& Viner, 2006; Jopp, Mair, DeLacy, \& Fluker, 2015). Thus, tourism is both a potential victim of and a significant contributor to climate change (Han, Lee, \& Hwang, 2016).

\section{Methods and Materials}

This paper analyses the importance of tourism for the Croatian economy, the impact of climate change on tourism and the necessity of an adjustment process. The conceptual part of the research relies on financial and nonfinancial secondary international data, publicly available on the websites of the World Travel and Tourism Council (WTTC) and the Croatian Bureau of Statistics, and the Croatian Meteorological and Hydrological Service. The paper analyzes and compares the number of arrivals, the number of overnight stays, tourism income, gross domestic product and exports. To investigate what the experts involved in tourism think about the impact of climate change on Croatian tourism, this study employed a qualitative approach to obtain comprehensive insights into tourism and climate change impacts. A team of experts on adaptation to climate change convened a workshop entitled "Modelling Climate Scenarios, Assessing the Impact of Climate Change on the Basis of the Results Obtained by Modelling and Evaluating Climate Change Adaptation Measures, and Introduction to the Existing Adaptation Solutions and Technologies", which was held in Zagreb 

Table 1. Economic Contribution of Tourism in Croatia for the period 2004-2015

\begin{tabular}{|c|c|c|c|c|c|}
\hline \multirow[b]{2}{*}{ Year } & \multicolumn{2}{|c|}{ Numerical indicators - in 000} & \multirow{2}{*}{$\begin{array}{c}\text { Tourism } \\
\text { revenue in } \\
\text { million EUR }\end{array}$} & \multirow{2}{*}{$\begin{array}{c}\text { GDP in million } \\
\text { EUR }\end{array}$} & \multirow{2}{*}{$\begin{array}{c}\text { Tourism share } \\
\text { in GDP }\end{array}$} \\
\hline & $\begin{array}{c}\text { Number of } \\
\text { arrivals }\end{array}$ & $\begin{array}{c}\text { Number of } \\
\text { overnight stays }\end{array}$ & & & \\
\hline 2004 & 9,412 & 47,797 & 5,505 & 27,379 & 20.1 \\
\hline 2005 & 9,995 & 41,421 & 5,998 & 30,950 & 19.4 \\
\hline 2006 & 10,385 & 53,007 & 6,293 & 34,234 & 18.3 \\
\hline 2007 & 11,162 & 56,005 & 6,752 & 42,810 & 15.7 \\
\hline 2008 & 11,261 & 57,103 & 7,449 & 47,390 & 15.7 \\
\hline 2009 & 10,935 & 56,301 & 6,379 & 45,093 & 14.1 \\
\hline 2010 & 10,604 & 56,416 & 6,236 & 45,917 & 13.6 \\
\hline 2011 & 11,456 & 60,354 & 6,598 & 45,894 & 14.4 \\
\hline 2012 & 11,835 & 62,743 & 6,843 & 44,223 & 15.5 \\
\hline 2013 & 12,434 & 64,818 & 7,188 & 43,478 & 16.5 \\
\hline 2014 & 13,128 & 66,484 & 7,402 & 43,002 & 17.2 \\
\hline 2015 & 14,343 & 71,605 & 8,115 & 43,846 & 18.5 \\
\hline \multicolumn{6}{|c|}{ Descriptive Statistics } \\
\hline Standard Deviation & 1,374 & 8,231 & 693,2 & $6,533.2$ & 2.09 \\
\hline Minimum & 9,412 & 41,421 & 5,505 & 27,239 & 13.6 \\
\hline Maximum & 14,343 & 71,605 & 8,115 & 47,390 & 20.1 \\
\hline Mean & 11,412 & 57,837 & 6,716 & 41,184 & 16.5 \\
\hline
\end{tabular}

Source: Adapted from „Tourism in figures 2017“ by the Republic of Croatia (2018). Zagreb: The Ministry of Tourism. Retrieved from https://mint.gov.hr/UserDocsImages//AA_2018_c-dokumenti//180608_HTZTUBENG_2017.PDF

frastructure, rich cultural and historical heritage and other important segments of tourist services (Institute for Tourism, 2013). It is expected that Croatian tourism will increase its diversity, offer a whole new range of products and services, significantly raise the quality of it services and identify new trends in the behavior of modern tourists (e.g., greater use of closer and safer destinations, increase in short and frequent travel, increased interest in cultural events, focus on active holidays, environmental awareness, and value-based pricing). This, in turn, might result in the achievement of the very optimistic results estimated by the WTTC (Institute for Tourism, 2013).

\section{Expected Climate Change and Guidelines for Future Tourism Development}

Climate change is already being recognized by a majority of governments and scientists throughout the world as a significant social and environmental issue facing the global population and its resources (Wise et al., 2014). Climate change is expected to bring substantially higher temperatures (Intergovernmental Panel on Climate Change [IPCC], 2014) and to specifically impact the coastal Mediterranean region (Filipe, Lawrence, \& Bonada, 2013). The vulnerability of tourism in coastal areas will depend on the levels of exposure, sensitivity and the adaptive capacity of the destination 
Table 2. Significant Economic Variables in Selected Mediterranean Countries in 2015

\begin{tabular}{|c|c|c|c|c|c|c|}
\hline Country & $\begin{array}{c}\text { Tourism } \\
\text { revenues (in } \\
\text { million EUR) }\end{array}$ & $\begin{array}{l}\text { GDP (in million } \\
\text { EUR) }\end{array}$ & $\begin{array}{l}\text { Export (in } \\
\text { million EUR) }\end{array}$ & $\begin{array}{l}\text { Export share } \\
\text { in total GDP } \\
\text { (in } \%)\end{array}$ & $\begin{array}{c}\text { Tourism } \\
\text { revenues share } \\
\text { in total GDP } \\
\text { (in } \%)\end{array}$ & $\begin{array}{c}\text { Tourism } \\
\text { revenues share } \\
\text { in total export } \\
\text { (in \%) }\end{array}$ \\
\hline Greece & 14,398 & 175,697 & 56,073 & 32 & 8 & 26 \\
\hline Spain & 51,930 & $1,075,639$ & 356,873 & 33 & 5 & 14 \\
\hline France & 36,242 & $2,181,064$ & 654,922 & 30 & 2 & 5 \\
\hline Italy & 42,186 & $1,642,443$ & 493,679 & 30 & 3 & 9 \\
\hline Cyprus & 2,277 & 17,637 & 10,797 & 61 & 13 & 21 \\
\hline Malta & 1,257 & 9,250 & 13,264 & 43 & 13 & 9 \\
\hline Portugal & 11,581 & 179,539 & 72,812 & 40 & 7 & 16 \\
\hline Croatia & 8,115 & 43,846 & 21,912 & 50 & 18 & 37 \\
\hline
\end{tabular}

Source: Adapted from "UNWTO Tourism Highlights" by WTO (2016). Retrieved from https:/www.e-unwto.org/doi/ pdf/10.18111/9789284418145

(Schliephack \& Dickinson, 2017). Weather and climate can therefore act as both push and pull factors, and there is also a strong relationship between weather and travel (Becken \& Wilson, 2013). Thus, tourism business, destinations, transit routes and tourists are all sensitive to the variability and change in climate and weather parameters, which affect the length and quality of tourism seasons and tourist experiences as well as the sustainability of tourism resources (Gössling, et al., 2010).

In Croatia, climate is especially important for tourism (Šverko Grdić \& Krstinić Nižić, 2016). This is particularly true of its summer months with mild temperatures, very little rain on the coast, a lot of sunshine and rare extreme weather conditions (Tudor, Ivatek Šahdan, Stanešić, Horvat, \& Bajić, 2013). Figure 1 below shows an overview of the types of climate in Croatia according to the Köppen classification used by many scientists dealing with climate change (Teichmann, Eggert et al., 2013).

The warmest area is on the coast, characterized by the lowest temperature differences between the seasons and the highest levels of tourist activity, i.e., Dalmatia and the North (upper) Adriatic. The coldest is the mountainous area, with little tourist activity and the largest differences between winter and summer tem- peratures. The Pannonian area and the city of Zagreb have colder autumn and winter periods than the areas along the coast. The coldest month is January, with an average temperature of $-2^{\circ} \mathrm{C}$ in the mountainous areas and up to $5^{\circ} \mathrm{C}$ in the coastal region. The warmest month is July, with an average temperature of $15^{\circ} \mathrm{C}$ in the mountainous and $24^{\circ} \mathrm{C}$ in the coastal part of Croatia. Research results indicate that an ideal maximum temperature should be approximately $30^{\circ} \mathrm{C}$ (Maddison, 2001), while the optimal average daily temperature should be approximately $21^{\circ} \mathrm{C}$ (Amelung \& Viner, 2006). These data clearly show that the temperature of the Croatian coastal area is already higher than the desirable, i.e., optimal, temperature according to tourists. The majority of tourist activity takes place outdoors, and tourists can still count on a large number of sunny days and favorable climate conditions during their holidays. Tourist traffic in Croatia is strongly centered in the Adriatic region, which is to be expected considering that Croatian tourism is a distinctly summer phenomenon, with the June-September period accounting for $75.5 \%$ of tourist arrivals and $85.7 \%$ of overnight stays (Galičić, 2015). Inland attractions are also associated with outdoor activities, including a substantial amount of ecotourism in the national parks and nature parks. All these features, which make tourist destina- 


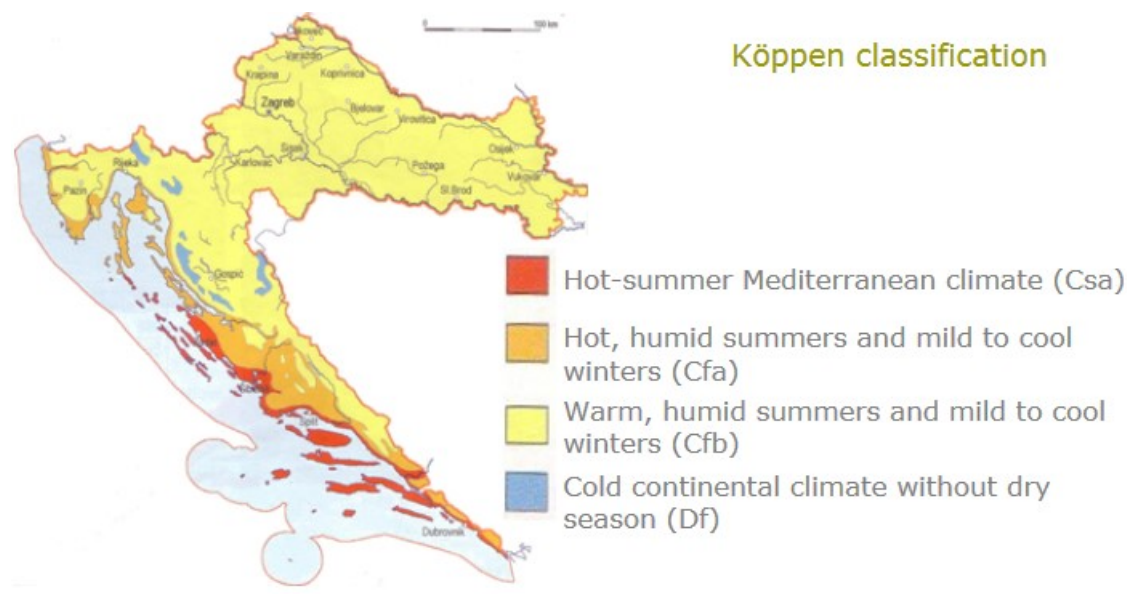

Figure 1. Types of climate in Croatia - the Köppen classification Source: Adapted from "Climate Change Consequences in Croatia - Grooming Disasters" by N. Holcinger (2011). [Power Point slides]. Retrieved from http://www.macefdrr.gov.mk/files/prezentacii/climate/CCA_CRO.ppt

tions attractive, are vulnerable to climate change (Patterson, Bastianoni, \& Simpson, 2006).

Between now and 2030, the climate in Croatia will remain about the same. This statement is corroborated by in-depth interviews conducted with 15 experts from the research, tourism, education, and decisionmaking sectors. All of them believe that climate change in the near future will not harm tourism, but that after 2030, a number of adaptation measures will be required to maintain the current tourism status. Their common opinion is that the problem of climate change in Croatia is little discussed and even less known. They find the tourism and hospitality workers insufficiently interested in the problems whose consequences may be felt in 10-15 years. From these interviews, it can also be concluded that in the next ten years, climate change will in no way compromise Croatian tourism. Such a medium-term projection is probably the reason why tourism professionals are not showing a concern. However, in planning larger and longer-term investments, it must be taken into consideration that climate change may affect the structure of accommodation and extend the tourist season. The interviewed experts stressed the need for the government and ministries dealing with tourism and environmental protection to conduct various educational campaigns to raise climate change awareness.

These considerations agree with the projections of the Croatian Meteorological and Hydrological Service for the period 2041-2070, using several models and predicting the following changes (Republic of Croatia, 2010):

- Winter: the temperature in northern Croatia will increase by $2.5^{\circ} \mathrm{C}$; in the rest of Croatia, the increase will be $2-2.5^{\circ} \mathrm{C}$. Precipitation is likely to increase in the north and decrease in the south. The occurrence of snow in northern Croatia will become uncertain.

- Spring: temperature will increase by $1.5^{\circ} \mathrm{C}$ both inland and along the coast. A slight decrease in precipitation is likely to occur in southern and western Croatia (9 millimeters decrease). 



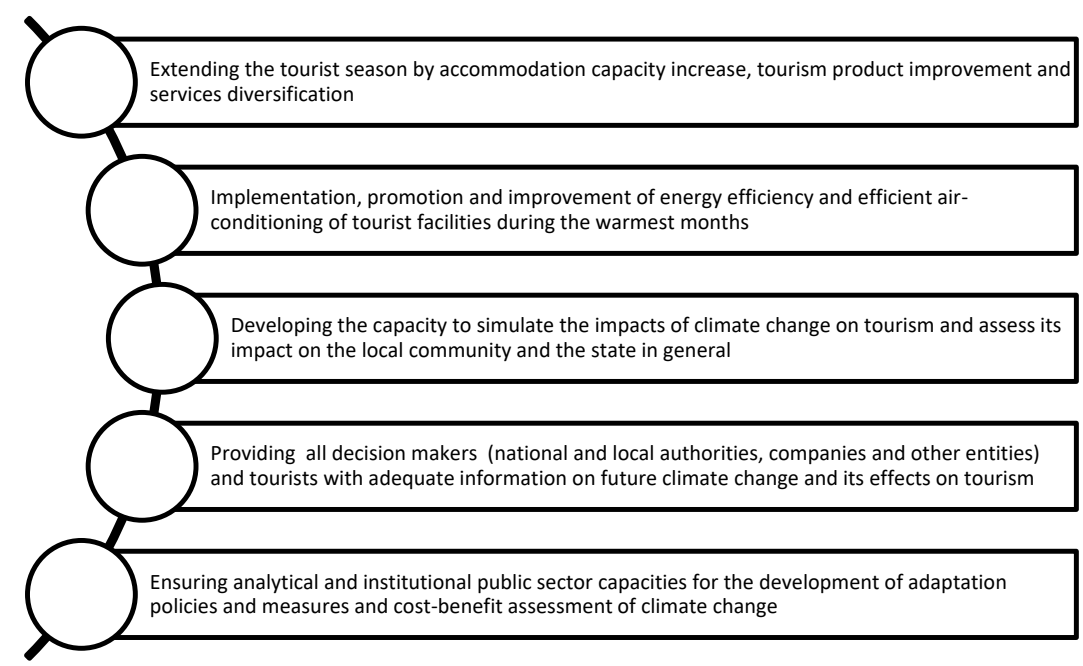

Figure 2. Climate change adaptation measures and activities

Technical

Figure 3. Matrix of stakeholders' activities in the process of adapting the tourism sector to climate change 
ment implies the establishment of a normative framework that would allow Croatia to more easily conform to the European Union framework for climate change. The adoption and implementation of the legal framework will establish and regulate environmental quality. Political type of adaptation in tourism requires industry strengthening by providing economic incentives, primarily to small businesses in the tourism industry. The government will have to ensure the strengthening of the overall economic development by introducing a series of investment and tax measures that will encourage development. In terms of political activities, the financial and insurance sectors will need to finance various development models in the tourism sector as well as the entire Croatian economy. Educational type of adjustment is among the most important forms of measures and actions, since without quality education, it is not possible to take proper measures. This type of adjustment in tourism implies conducting educational campaigns for potential tourists and other stakeholders in the tourism industry, while the government will need to provide the general population with education on the mitigation of and adapting to climate change. The financial and insurance sectors will be involved through the informing and education of potential and existing customers.

These measures should allow Croatian tourism to adapt to new business conditions and facilitate the achievement of a quality performance even in the distant future.

\section{Conclusion}

In this study, the authors investigate the influence of tourism on economic growth and climate change. Croatian tourism in the observed eleven-year period achieved an overall growth for all indicators with the exception of "Tourism share in GDP", which shows an overall reduction in 2015. As foreign currency inflow affects macroeconomic stability, both the government and tourism professionals need to make the tourism revenue share as high as possible in the total gross domestic product. Tourism represents one of the most important economic activities in Croatia and is therefore crucial for ensuring positive results in the future. However, as tourism in Croatia is extremely seasonal and depends on weather conditions, a stronger impact of climate change could have negative effects on tour- ism. If higher temperatures in the summer months result in tourists' avoidance of the coastal areas of Croatia, this could lead to increased unemployment, the closure of smaller accommodation and catering facilities, population migration and a general decrease in the living standards of the population involved in tourism. The survey results show that by 2030 , there will be no significant changes in terms of climate change but that it is also necessary to inform key stakeholders and the public about climate change adaptation measures. As a member of the European Union, Croatia must follow the European Union climate change policies. However, as climate change adaptation is a multilevel problem, government activity cannot remain restricted to the national level; it is particularly important to act at the regional and local levels as well. Climate affects the length as well as the quality of the tourism season, the tourism destination choice and tourism expenditure. This study can help all stakeholders in the tourism industry, especially those involved at the local and regional levels, to interpret global and regional climate change signals and to implement technical, legislative, political and educational measures for climate change adaptation. The contribution of this paper lies in the provision of information to decision makers, helping them diversify/adapt tourism services and products without relying solely on the mild Mediterranean climate and the "sun and sea" as the main product. It is up to the stakeholders to tackle the task of designing and ensuring the extension of the tourism season beyond summer months by designing a variety of new sports and cultural events. Only those that take a long-term view and care about their future today will be able to organize and adapt to new business conditions. A thoughtful approach to climate change adaptation will enable Croatian tourism to remain the leading economic activity.

\section{References}

Amelung, B., \& Moreno, A. (2012). Costing the impact of climate change on tourism in Europe: Results of the PESETA Project. Climatic Change, 112(1), 83-100.

Amelung, B., Nicholls, S., \& Viner, D. (2007). Implications of global climate change for tourism flows and seasonality. Journal of Travel Research, 45(3), 285-296. 
Amelung, B., \& Viner, D. (2006). Mediterranean tourism: Exploring the future with the tourism climatic index. Journal of Sustainable Tourism, 14(4), 349-366.

Balaguer, J., \& Cantavella-Jorda, M. (2002). Tourism as a long-run economic growth factor: The Spanish case. Applied Economics, 34(7), 877-884.

Becken, S., \& Wilson J. (2013). The impacts of weather on tourist travel. Tourism Geographies: An international Journal of Tourism Space, Place and Environment, 15(4), 620-639.

Blažević, B. (2007). Turizam u gospodarskom sustavu [Tourism in economic system]. Opatija: University of Rijeka. Faculty of Tourism and Hospitality Management.

Bowen, A., Cochrane, S., \& Fankhauser, S. (2012). Climate change, adaptation and economic growth. Climatic Change, 113(2), 95-106.

Brau, R., Lanza, A., \& Pigliaru, F. (2007). How fast are small tourism countries growing? Evidence from the Data for 1980-2003. Tourism Economics, 13(4), 603-613.

Buckley, R. (2011). Tourism and environment. Annual Review of Environmental and Resources, 36, 397416.

Casado-Asensio, J., \& Steurer, R. (2014). Integrated strategies on sustainable development, climate change mitigation and adaptation in Western Europe: Communication rather than coordination. Journal of Public Policy, 34(3), 437-473.

Dell, M., Jones, B. F., \& Olken. B. A. (2012). Temperature shocks and economic growth: Evidence from the last half century. American Economic Journal: Macroeconomics, 4(3), 66-95.

Dickinson, J. E., Robbins, D., Tilimonau, V., Hares, A., \& Mika, M. (2013). Awareness of tourism impacts of climate change and the implications for travel practice: A Polish perspective. Journal of Travel Research, 52(4), 506-519.

Dritsakis, N. (2004). Tourism as a long-run economic growth factor: An empirical investigation for Greece using causality analysis. Tourism Economics, 10(3), 305-311.

Dulal, H. B., Shah, K. U., \& Ahmad N. (2009). Social equity considerations in the implementation of caribbean climate change adaptation policies. Sustainability, 1, 363-383.
Dwyer, L., Forsyth, P., Spurr, R., \& Hoque, S. (2012). Economic impacts of a carbon tax on the Australian tourism industry. Journal of Travel Research, 52(2), 143-155.

Eboli, F., Parrado, R., \& Roson, R. (2010). Climate change feedback on economic growth: Explorations with a dynamic general equilibrium model. Environment and Development Economics, 15(5), 515-533.

Republic of Croatia. (2010, January). Fifth National Communication to the United Nations Framework Convention on Climate. Zagreb: Ministry of Environmental Protection, Physical Planning and Construction Retrieved from https://unfccc.int/ resource/docs/natc/hrv_nc5.pdf

Figini, P., \& Vici, L. (2009). Tourism and growth in a cross-section of countries (Working Paper No. 08-09). Rimini Centre for Economic Analysis. Retrieved from http://www.rcea.org/RePEc/pdf/ wp01_09.pdf

Filipe, A. F., Lawrence, J. E., \& Bonada, N. (2013). Vulnerability of stream biota to climate change in Mediterranean climate regions: A synthesis of ecological responses and conservation challenges. Hydrobiologia, 719(1), 331-351.

Galičić, V. (2015). Tourism in Croatia: Truths and misconceptions. Informatol, 48(1-2), 78-94.

Gössling, S., Hall, C. M., Peeters, P., \& Scott, D. (2010). The future of tourism: Can tourism growth and climate policy be reconciled? A mitigation perspective. Tourism Recreation Research, 35(2), 119-130.

Gössling, S., Scott, D., \& Hall, M. (2013). Challenges of tourism in a low carbon economy. WIREs Clim Change, 4(6), 525-538.

Hamilton, J. M., \& Tol, R. S. J. (2007). The impact of climate change on tourism in Germany, the UK and Ireland: A simulation study. Regional Environment Change, 7(3), 161-172.

Han, J. H., Lee, M. J., \& Hwang, Y. S. (2016). Tourists' environmentally responsible behaviour in response to climate change and tourist experiences in nature based tourism. Sustainability, 8(7). https://doi.org/10.3390/su8070644.

Hein, L., Metzger, M. J., \& Moreno, A. (2009). Potential impacts of climate change on Tourism; A case study for Spain. Current Opinion in Environmental Sustainability, 1(2), 170-178. 
Holcinger, N. (2011). Climate Change Consequences in Croatia - Grooming Disasters [PowerPoint slides]. Retrieved from http://www.macefdrr.gov. mk/files/prezentacii/climate/CCA_CRO.ppt

IPCC. (2014). Climate Change 2014, Impacts, Adaptation and Vulnerability, Part B, Regional Aspects. New York, NY: Cambridge University Press. Retrieved from https://www.ipcc.ch/site/assets/uploads/2018/02/WGIIAR5-PartB_FINAL.pdf

Jopp, R., Mair, J., DeLacy, T., \& Fluker, M. (2015). Climate change adaptation: Destination management and the green tourist. Tourism Planning \& Development, 12(3), 300-320.

Konrad, K. A., \& Thum, M. (2013). The role of economic policy in climate change adaptation. CESifo Economic Studies, 60(1), 32-61.

Landau, S., Legro, S., \& Vlašić, S. (2008). A climate for change, climate change and its impacts on society and economy in Croatia. Human Development Report. Zagreb: UNDP. Retrieved from http://hdr. undp.org/sites/default/files/nhdr_2008_en_croatia.pdf

Lee, W. J., \& Brahmasrene, T. (2013). Investigating the influence of tourism on economic growth and carbon emissions: Evidence from panel analysis of the European Union. Tourism Management, 38, 69-76.

Maddison, D. (2001). In search of warmer climates? The impact of climate change on flows of British Tourists. Climatic Change, 49(1/2), 193-208.

Ministry of Tourism. Republic of Croatia. (2013, February). Croatian Tourism Development Strategy until 2020 [PowerPoint slides]. Retrieved from https://mint.gov.hr/UserDocsImages//arhiva// Strategy-tourism.present.pdf

Müller, H., \& Weber, F. (2008). Climate change and tourism - scenario analysis for the Bernese Oberland in 2030. Tourism Review, 63(3), 57-71.

Patterson, T., Bastianoni, S., \& Simpson, M. (2006). Tourism and climate change: Two-way street, of vicious/virtuous circle. Journal of Sustainable Tourism, 14(4), 339-348.

Payne, J. E., \& Mervar, A. (2010). The tourism growth nexus in Croatia. Tourism Economics, 16(4), 10891094.

Perch Nielsen, S. L., Amelung, B., \& Knutti, R. (2010). Future climate resources for tourism in Europe based on the daily tourism climatic index. Climatic Change, 103(3/4), 363-381.

Pickering, C. (2011). Changes in demand for tourism with climate change: A case study of visitation patterns to six ski resorts in Australia. Journal of Sustainable Tourism, 19(6), 767-781.

Schliephack, J., \& Dickinson, J. E. (2017). Tourists' representations of coastal managed realignment as a climate change adaptation strategy. Tourism Management, 59, 182-192.

Schubert, S. F., Brida, J. G., \& Risso, W. A. (2011). The impacts of international tourism demand on economic growth of small economies dependent on tourism. Tourism Management, 32(2), 377-385.

Scott, D., \& Becken, S. (2010). Adapting to climate change and climate policy: Progress, problems and potentials. Journal of Sustainable Tourism, 18(3), 283-295.

Seetanah, B. (2011). Assessing the dynamic economic impact of tourism for Island economies. Annals of Tourism Research, 38(1), 291-308.

Shani, A., \& Arad, B. (2014). Climate change and tourism: Time for environmental skepticism. Tourism Management, 44, 82-85.

Šverko Grdić, Z., \& Krstinić Nižić, M. (2016). Development of tourist demand in correlation with climate change in the Republic of Croatia. Ekonomski pregled, 67(1), 27-43.

Teichmann, C., Eggert, B. Elizalde, A., Haensler, A., Jacob, D., Kumar, P.,...Weber, T. (2013). How does a regional climate model modify the projected climate change signal of the friving GCM: A study over different CORDEX regions using REMO. Atmosphere, 4(2), 214-236.

The Republic of Croatia. (2018). Tourism in figures 2017. Zagreb: The Ministry of Tourism. Retrieved from https://mint.gov.hr/UserDocsImages//AA_2018_c-dokumenti//180608_HTZTUBENG_2017.PDF

Tudor, M., Ivatek Šahdan, S., Stanešić, A., Horvat, K., Bajić, A. (2013). Forecasting Weather in Croatia Using ALADIN Numerical Weather Prediction Model. In R. Pallav \& Y. Zhang (Eds.), Climate change and Regional/Local Responses (pp. 59-88). London, UK: Intechopen. Available at https://www.intechopen. com/books/climate-change-and-regional-localresponses/forecasting-weather-in-croatia-using-aladin-numerical-weather-prediction-model 
The World Tourism Organization. (2016). UNWTO Tourism Highlights. Retrieved from https://www.eunwto.org/doi/pdf/10.18111/9789284418145

Webster, C., \& Ivanov, S. (2014). Transforming competitiveness into economic benefits: Does tourism stimulate economic growth in more competitive destinations? Tourism Management, 40, 137-140.

Wise, R. M., Fazey, I., Smith, M. S., Park, S. E., Eakin, H. C., Van Gardern E. R. M. A...... Campbell, B. (2014). Reconceptualising adaptation to climate change as part of pathways of change and response. Global Environmental Change, 28, 325-336.

\section{Acknowledgements}

This paper was financially supported by the University of Rijeka for project ZP UNIRI 4/15. 